\title{
Modeling, Simulation and Control of Fuel Cell Based Micro Grid
}

\author{
Shikha Gupta, Rachana Garg and Alka Singh \\ Delhi Technological University, EED, Shahabad Daultpur, \\ Bawana Road, Delhi 110042 \\ E-mail:shikhaguptadtu@gmail.com; rachana16100@yahoo.co.in; \\ alkasingh.dr@gmail.com
}

\author{
Received 14 April 2017; Accepted 19 July 2017; \\ Publication 18 August 2017
}

\begin{abstract}
In near future, fuel cell (FC) based power generation system will witness higher scalability due to merits like reliability, portability and negligible environmental impact. This paper presents grid integrated fuel cell generator as micro grid and interacts with modeling and simulation of control architecture (voltage, active and reactive power) along with vital design aspect of interface filter. The fuel cell system output is connected to current controlled voltage source converter (VSC) which controls active and reactive power. Power balance control theory (PBCT) is used to generate gate pulses for VSC. Hybrid fuzzy PI controller is used to attain constant DC link voltage. Simulation of entire system based on fuel cells is undertaken through MATLAB/Simulink software. PBCT and synchronous reference frame theory (SRFT) control strategies are also compared for grid connected FC system.
\end{abstract}

Keywords: SOFC, Power balance control theory, voltage source converter (VSC), hybrid FLC, renewable energy sources.

Journal of Green Engineering, Vol. 7, 129-158.

doi: 10.13052/jge1904-4720.7127

(C) 2017 River Publishers. All rights reserved. 


\section{List of Abbreviations}

FC Fuel Cell

SOFC Solid Oxide Fuel Cell

VSC Voltage Source Converter

PBCT Power Balance Control Theory

SRFT Synchronous Reference Frame Theory

RES Renewable Energy Sources

GCFC Grid Connected Fuel Cell

PCC Point of Common Coupling

\section{List of Notations}

\begin{tabular}{|c|c|}
\hline$q_{H_{2}}^{c}$ & Consumed Hydrogen Flow (mol/s) \\
\hline$q_{H_{2}}^{i}$ & Inlet Hydrogen Flow (mol/s) \\
\hline $\mathrm{K}_{\mathrm{c}}$ & Constant $(\mathrm{mol} /(\mathrm{s} \mathrm{A}))$ \\
\hline$I_{f c}^{c}$ & FC System Feedback Current (A), \\
\hline N & Number of Series Cells in SOFC Stack, \\
\hline $\mathrm{F}$ & Faraday’s Constant (C/mol) \\
\hline $\mathrm{R}$ & Universal Gas Constant $(\mathrm{J} /(\mathrm{mol} \mathrm{K}))$ \\
\hline $\mathrm{T}$ & Absolute Temperature in SOFC (K) \\
\hline $\mathrm{V}_{\mathrm{a}}$ & Volume of the Anode \\
\hline $\mathrm{pH}_{2}$ & Partial Pressure of Hydrogen Gas (atm) \\
\hline$n_{H_{2}}$ & Number of Hydrogen Moles in the Anode Channel \\
\hline$q_{H_{2}}^{o}$ & Output Hydrogen Flow (mol/s) \\
\hline$q \mathrm{H}_{2}$ & Molar Flow of Hydrogen $[\mathrm{kmol} / \mathrm{s}]$ \\
\hline$K_{H_{2}}$ & Hydrogen Flow Valve Molar Constant (mol/(s atm)) \\
\hline$M_{H_{2}}$ & Molecular Masses of Hydrogen $(\mathrm{kg} / \mathrm{kmol})$ \\
\hline $\mathrm{K}_{\mathrm{a}}$ & Anode Valve Constant $\left[\sqrt{ } \mathrm{kmol} \cdot \mathrm{Kg}(\mathrm{atm} \cdot \mathrm{s})^{-1}\right]$ \\
\hline$\sigma_{H_{2}}$ & Time Constant Of Hydrogen Flow (s) \\
\hline $\mathrm{r}$ & Total Ohmic Loss of SOFC Stack (ohm) \\
\hline $\mathrm{E}_{0}$ & Thermodynamic Potential(V) \\
\hline$p_{\mathrm{H}_{2}} \mathrm{O}$ & Partial Pressure of Water (atm.) \\
\hline$p_{\mathrm{O}_{2}}$ & Partial Pressure of Oxygen Gas (atm.) \\
\hline$V_{\text {grid }}$ & Grid r.m.s. Phase Voltage, \\
\hline$f_{s w}$ & Inverter Switching Frequency \\
\hline$i_{\text {r.p. }}$ & $15 \%$ of rated output current \\
\hline $\mathrm{L}_{\mathrm{a}}$ & Grid Side Inductance \\
\hline $\mathrm{L}_{\mathrm{b}}$ & Inverter Side Inductance \\
\hline $\mathrm{C}$ & Capacitance of LCL Filter \\
\hline
\end{tabular}




$\begin{array}{ll}\mathrm{P}_{\mathrm{i}} & \text { Indicates Rated Power of Inverter } \\ \mathrm{c}_{\mathrm{b}} & \text { Base Capacitance } \\ \mathrm{Z}_{\mathrm{b}} & \text { Base Impedance } \\ \mathrm{V}_{\mathrm{gLL}} & \text { Represents Grid Line Voltage } \\ \omega_{\mathrm{n}} & \text { Stands for Operating Frequency } \\ V_{d c, a c t} & \text { DC Terminal Measured Voltage across DC Link } \\ V_{d c} * & \text { Applied Set Point Input (800V) or reference voltage }\end{array}$

\section{Introduction}

Continuous and accelerating energy demand across the globe has stimulated opportunity for renewable energy sources (RES) in energy market. In near future, RES will dominate the market due to lack of any other sustainable alternative. Among the available RES, fuel cell footprints are gaining prominence and growing at rapid pace. Higher efficiency, low emissions, less noise and high modularity are some of lucrative attributes of fuel cell [1]. Based on the concept and components, FC is segmented into Solid Oxide Fuel Cells (SOFC), Molten Carbonate Fuel Cells and Proton Exchange Membrane [1]. SOFC is a viable technology alternative for power production in the range of few $\mathrm{kW}$ to hundreds of $\mathrm{kW}$ due to availability of wide range of hydrocarbon based fuels, higher operating temperature and higher power conversion efficiency. In a grid connected fuel cell (GCFC) system, the integration of FC stacks to the grid has to meet performance parameters related to power quality, reliability and safety aspects [2]. These functional requirements related to integration and control requires power conditioning unit (PCU) to maintain defined performance parameters. Different topologies for the PCU are given in [3-7]. DC-DC boost converter and current controlled VSC are used as PCU in this paper and control of VSC is based on PBCT. Different types of control methods have been discussed in the literature viz. p-q theory [8, 9], Fryzes theory [10], synchronous d-q reference frame theory (SRFT) [11] etc. These methods require several transformations for conversion from to $\alpha \beta$ to dq frame of reference and back. Adaptive control algorithm has been also applied for power quality improvement [12]. PBCT has been applied for DSTATCOM [13], and gives satisfactory response when used for active filtering and load compensation. A definite advantage of this algorithm is that it does not need PLL for grid synchronization, less computational complexity is required and gives better performance under variety of load conditions. 


\section{S. Gupta et al.}

Grid integration has necessary requirement of a filter at the output for effective interface. The design of filter plays an important role and is a critical issue in grid connected topology for stability of the system and to reduce the ripples. L, LC, LCL filter may be used as filter configurations. The LC filter configuration involves computation of only two parameters making it less complex but has inferior filtering effect. Improper output in this configuration is due to uncertainty of network impedance and also becomes very costly for higher and medium power network [14]. Ripple attenuation at high frequencies can be effectively attained using LCL filter [15] which also has advantage of better decoupling between the filter and the grid impedance. Presence of filter capacitor reduces current ripple across grid side inductor [16]. Further, Due to sudden change of load, a disturbance in DC link voltage results, which needs to be damped rapidly to ensure reliable and steady operation. Hence, it is necessary to incorporate a DC link voltage controller which can maintain constant voltage level under major disturbances such as a sudden change in load. Which is subject of concern in various researches such as adaptive neuro fuzzy controller [17], adaptive PI controller [18] etc.

In this paper, model of $3 \mathrm{~kW}$ SOFC stack is simulated and DC-DC boost converter integrated to boost the output voltage of fuel cell. A three leg VSC is used to connect the FC system with the grid. For GCFC micro grid, designing factors of LCL filter are considered. Power balance control theory is implemented to control the inverter. This algorithm is based on template generation and grid voltage is taken as reference in this work. Proposed control of VSC also compensates reactive power, provides power factor correction, and limits the supply current harmonics and control ac voltage at point of common coupling (PCC). PI controller is used to regulate PCC voltage and hybrid fuzzy controller is used to maintain constant DC link. This paper demonstrates how the proposed hybrid fuzzy logic controller (H-FLC) can improve stability and performance of system. Functioning of H-FLC in comparison to conventional PI controller is better in terms of response under transient conditions whereas, PI controller shows better performance under steady state. The advantages of both FLC and PI controller are combined by implementing a hybrid Fuzzy-PI controller for DC terminal voltage control.

\section{Configuration and Design of Proposed System}

Figure 1 shows the configuration of proposed system where $3 \mathrm{~kW}$ fuel cell (FC) is integrated to the $800 \mathrm{~V} \mathrm{DC}$ bus through individual unidirectional DC-DC boost converter control unit. Control strategy of VSC is formulated such that it 


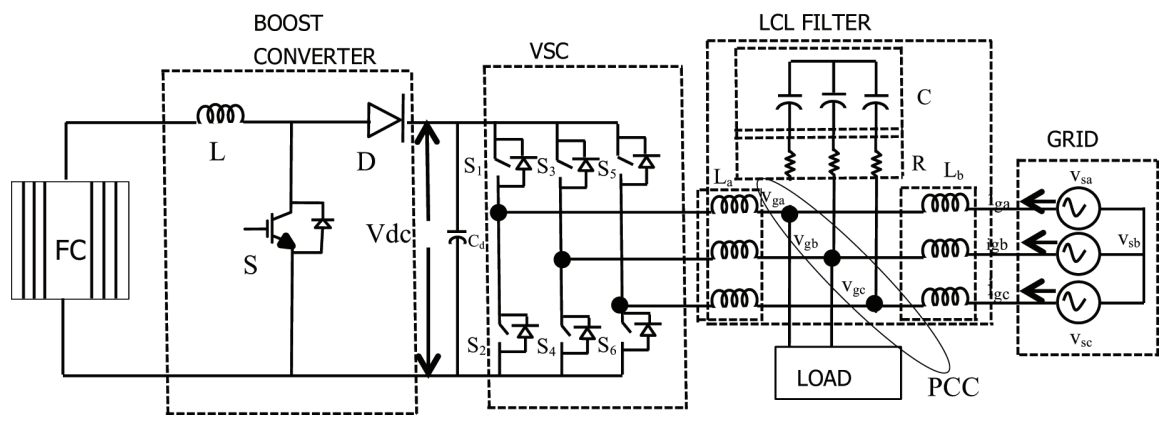

Figure 1 System configuration of proposed system.

ensures reliable and quality power supply to the load. The DC link is coupled to the utility grid through three phase VSC to perform DC/AC conversion. Design of VSC control is carried out to achieve reactive power compensation, load balancing and harmonic elimination.

\subsection{Fuel Cell Modeling}

The solid oxide fuel cell (SOFC) model [19] has been developed presuming that hydrogen and oxygen are fed to stack, temperature is constant and only ohmic loss will occur. Utilization factor (UF) is introduced for water molar fraction at the exhaust and taken is 0.85 . The UF is defined as the ratio of input fuel flow to the stack and consumed fuel and expressed as:

$$
U F=\frac{q_{H_{2}}^{c}}{q_{H_{2}}^{i}}
$$

Consumed molar flow of hydrogen can be calculated on the basis of electrochemical equation

$$
\begin{aligned}
q_{H_{2}}^{c} & =\frac{N I_{f c}^{c}}{2 F}=2 I_{f c}^{c} K_{c} \\
q_{H_{2}}^{i} & =\frac{2 K_{c} I_{f c}^{c}}{0.85}
\end{aligned}
$$

To calculate the partial pressure, each gas has been considered separately and perfect gas equation is applied using hydrogen gas as an example given in Equation (4)

$$
p H_{2} V_{a}=n_{H_{2}} R T
$$


Differentiating pressure with respect to time gives,

$$
\frac{d p H_{2}}{d t}=\left(R T / V_{a}\right) q H_{2}
$$

Hydrogen molecular flow is the contributed by input fuel, output fuel and consumed fuel hence Equation (5) become

$$
\frac{d p H_{2}}{d t}=\left(R T / V_{a}\right)\left(q_{H_{2}}^{i}-q_{H_{2}}^{o}-q_{H_{2}}^{c}\right)
$$

It can be assumed that molar flow of hydrogen via valve is directly proportional to the pressure inside, it is possible to write:

$$
\frac{q H_{2}}{p H_{2}}=\frac{K_{a}}{\sqrt{M_{H_{2}}}}=K_{H_{2}}
$$

Replacing Equation (7) and (2) in Equation (6) and taking Laplace both sides, the expression is found to be

$$
\begin{gathered}
p_{H_{2}}=\frac{\frac{1}{K_{H_{2}}}}{1+\sigma_{H_{2}} s}\left(q_{H_{2}}^{i}-2 K_{c} I_{f c}^{c}\right) \\
\sigma_{H_{2}}=V_{a} / K_{H_{2}} R T
\end{gathered}
$$

Same operation is applied to all reactants and products, and on the application of Nernst's equation and Ohm's law the equation of stack voltage can be written as:

$$
V=N\left(E_{o}+\frac{R T}{2 F}\left[\ln \frac{P_{H_{2}} P_{O_{2}}^{0.5}}{P_{H_{2} O}}\right]\right)-r I_{f c}^{c}
$$

Figure 2 shows the SOFC stack dynamic model developed using the MATLAB/Simulink. The stack voltage output is connected at the DC input of the controlled voltage source and DC/DC boost converter is deployed to boost its voltage to $800 \mathrm{~V}$.

\subsection{LCL Filter Design}

The LCL filter configuration has two vital design aspects as depicted in Figure 3. The former part is related to design of $\mathrm{L}_{a}$ and $\mathrm{L}_{\mathrm{b}}$ which represents inverter and grid side inductance respectively. The latter one is related to design of capacitance. Design parameters are chosen to have proper configuration wherein higher order harmonic pass through the capacitor while the lower 


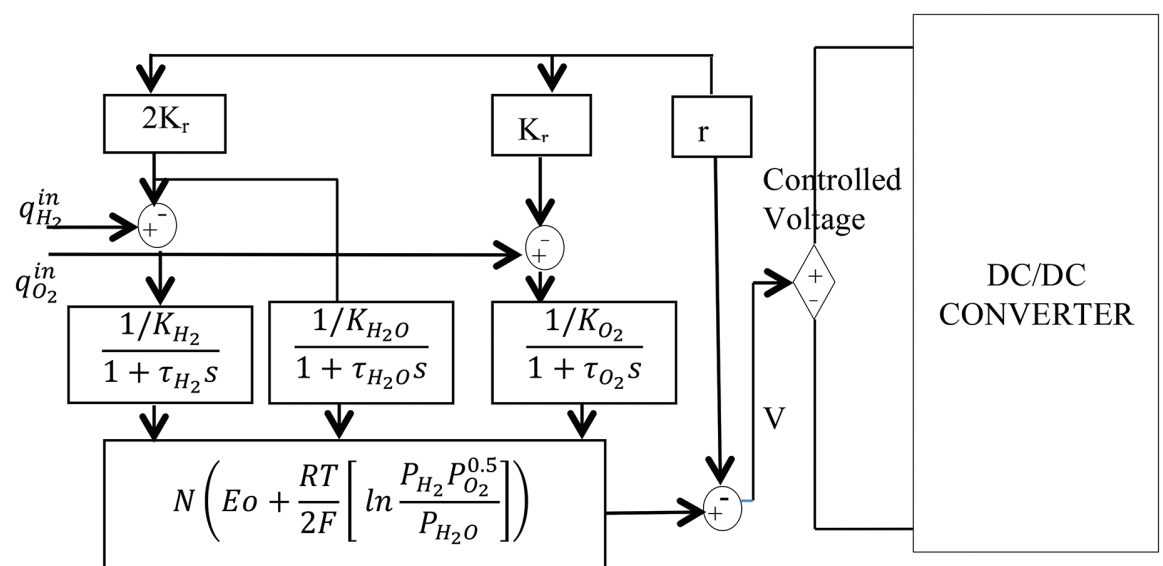

Figure 2 SOFC stack dynamic model.

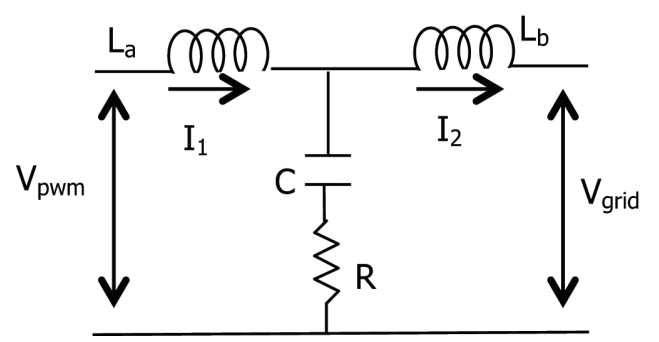

Figure 3 Circuit diagram of LCL Filter with damping resistor.

order harmonic flow through the inductor. The schematic layout of single phase LCL filter is presented in Figure 3. Bode plot is given in Figure 4. Transfer function of output current to input voltage (output voltage of inverter) with the damping resistance $\mathrm{R}$ is given as:

$$
\mathrm{G}(\mathrm{s})=\frac{\mathrm{I}_{2}}{\mathrm{~V}_{\mathrm{pwm}}}=\frac{\mathrm{R}}{\mathrm{S}^{3} \mathrm{~L}_{\mathrm{a}} \mathrm{L}_{\mathrm{b}} \mathrm{CR}+\mathrm{s}^{2} \mathrm{~L}_{\mathrm{a}} \mathrm{L}_{\mathrm{b}}+\mathrm{SR}\left(\mathrm{L}_{\mathrm{a}}+\mathrm{L}_{\mathrm{b}}\right)}
$$

Considering UPF system and PWM is implemented the total filter inductance can be represented by

$$
L=\frac{V_{\text {grid }}}{2 \sqrt{6 f_{\text {sw }} i_{r . p}}}(1-m) m
$$




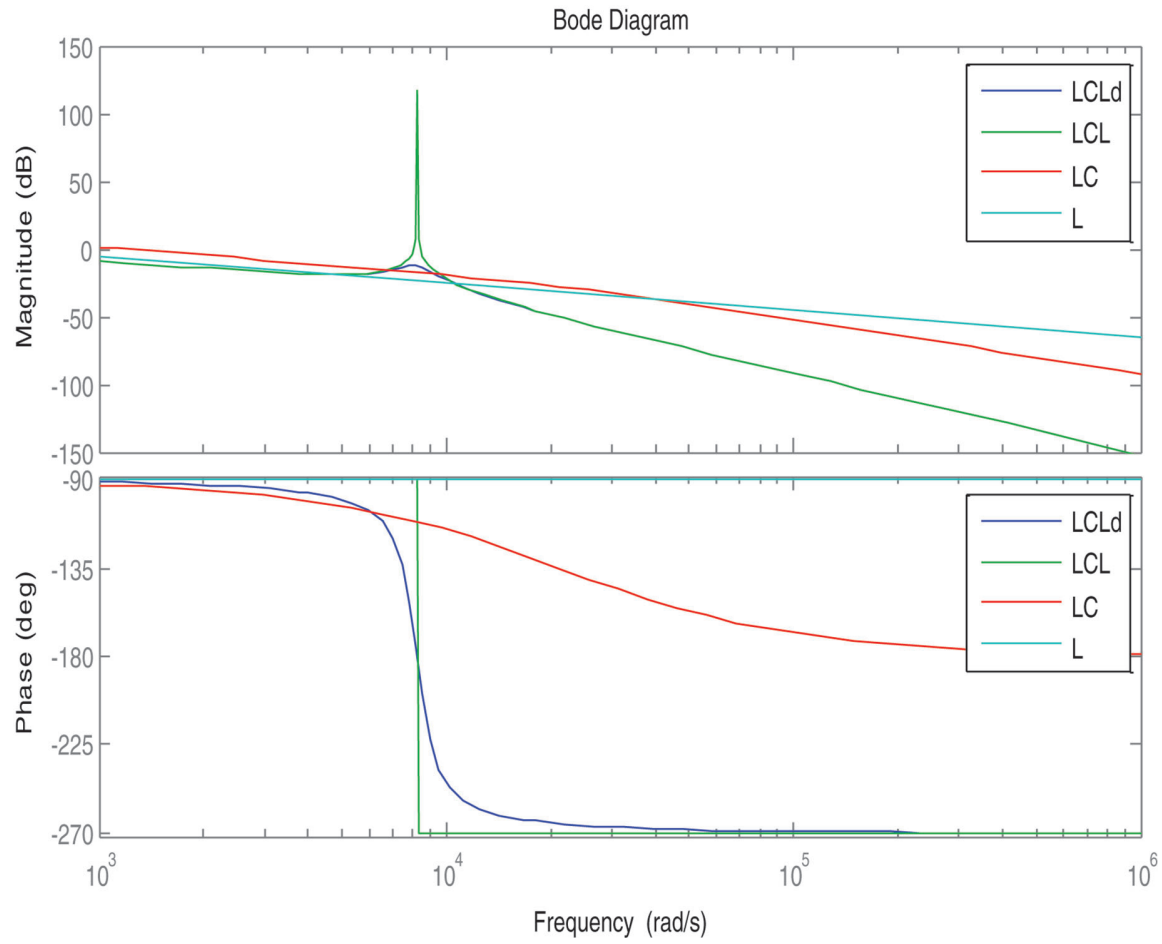

Figure 4 Bode plot of close loop system for L, LC and LCL filter with and without damping resister.

where $\mathrm{m}$ is modulation index. By adding a capacitor, the total filter inductance is divided into two parts: the inverter-side inductance and grid-side inductance. The relationship between these inductance values have been given in Equation (17). Computation of $\mathrm{L}_{\mathrm{a}}, \mathrm{L}_{\mathrm{b}}$ and $\mathrm{C}$ is summarized in [10, 16] and has been used in the calculations. The necessary design equations are listed in (12-17).

$$
\begin{aligned}
\mathrm{L}_{\mathrm{a}} & =\frac{V_{\text {grid }}}{2 \sqrt{6 f_{\text {sw }} i_{r \cdot p}}} \\
\mathrm{C} & \leq 0.05 c_{b} \\
c_{b} & =\frac{1}{\left(\omega_{n} Z_{b}\right)}
\end{aligned}
$$




$$
\begin{aligned}
Z_{b} & =\frac{V_{g L L}^{2}}{P_{i}} \\
\mathrm{C} & =0.025 c_{b} \\
L_{b} & =0.8 L_{a}
\end{aligned}
$$

$\mathrm{L}_{\mathrm{b}}$ is assumed to be a fraction of $\mathrm{L}_{\mathrm{a}}$, maybe greater than or lesser than $\mathrm{L} 1$. This is decided by further attenuation of current ripple $(20 \mathrm{~dB}$ taken in the designing consideration) at the switching frequency in the system or switching harmonic current attenuation ratio.

Due to $L_{a}$, current ripples are reduced. The stability analysis of filter and attenuation during switching frequency is computed through bode plot. Bode plot for the different filters (L, LC, LCL and LCLd) is shown in Figure 4. The cut off frequency is the estimated point at which the filters come to be effective. Prior to this frequency, the filter performance is not greatly affected, but in the high frequency region there is a marked difference. Good attenuation characteristics of the LCL and LCLd over LC and L filters are clearly visible from the Figure 4. It is observed that attenuation rate of LCL filter is $-60 \mathrm{~dB} / \mathrm{dec},-40 \mathrm{~dB} / \mathrm{dec}$ for LC filter and $-20 \mathrm{~dB} / \mathrm{dec}$ for the L filter. Good attenuation characteristics of LCLd filter are clearly evident in the high frequency region.

LCL filter shows better performance during high frequency range as compared to LC and L filters. The bandwidth of filters is almost same below the resonant frequency and the performance of LCL, LC and L filters shows approximately the same performance. But for the high frequency range, the LCL filter shows better attenuation characteristics than L and LC filter and moreover it attains the same filtering property using a smaller size and lower cost of component. In Figure 4 LCLd represents LCL filter with damping resistance. Addition of damping resister eliminates the resonance which results in reduction in peak of system resonance frequency.

Figure 5 depicts root locus diagram of closed-loop system having undamped and damped LCL filters respectively. In absence of damping resistor, the system's poles are on imaginary axis which shows LCL-filter is marginally stable. The use of damping resistor results in shifting of both poles of the system towards left side of imaginary axis indicating stable region and this ensures the stability of proposed system. The poles are observed to be $( \pm 0.5 j)$ in undamped case which get shifted to $(-0.5 \pm 0.5 \mathrm{j})$ position with damping effect introduced. 

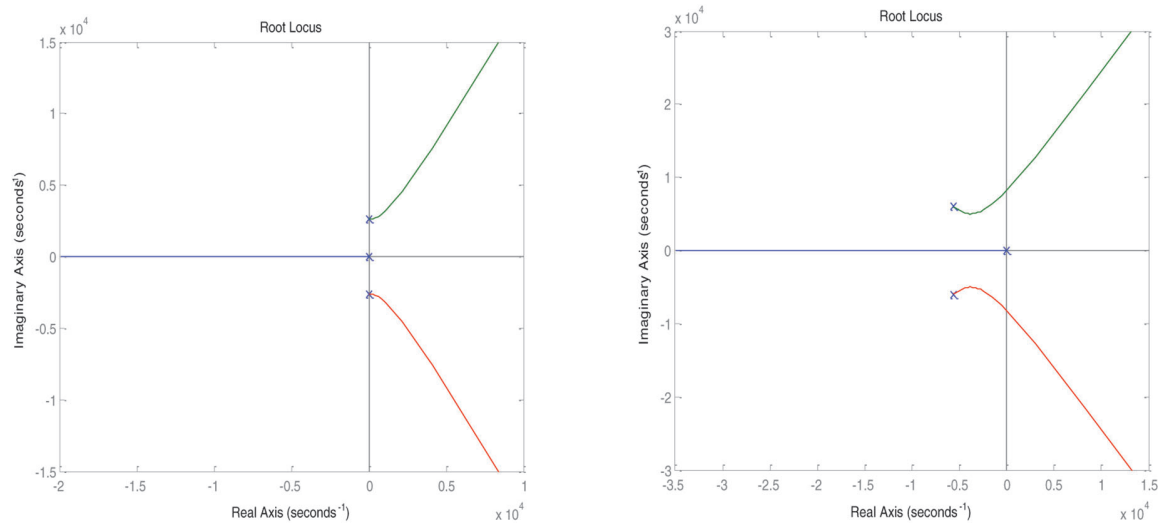

Figure 5 Root locus of LCL filters without and with damping resistance.

\subsection{Design of Fuzzy Controller for DC Link Voltage Regulation}

Active power flow needs to be controlled for keeping DC link voltage at fixed value. Active power flow is required to meet the losses occurring inside the VSC and thereby DC link voltage will be maintained at a constant value. The performance of VSC as a compensator depends upon the reference current generation and is designed in this paper for DC link voltage regulation.

Figure 6 shows the proposed fuzzy control unit, in which two inputs consisting of error and change in error are used to produce FLC output, while error only is fed to PI-controller to produce desired output. Both the outputs are added to produce the loss component of current $\left(\mathrm{i}_{\text {dloss }}\right)$ to regulate the DC terminal voltage. Figure 7 shows the output of PI, FLC and hybrid controller under transient condition (up to $0.4 \mathrm{~s}$ linear load is connected to the system and at $0.4 \mathrm{~s}$. linear load is disconnected and nonlinear load is connected) it can be observed that hybrid FLC shows superior response among the all three controller. The functioning of Fuzzy logic controller in comparison to conventional PI controller is better in terms of response under

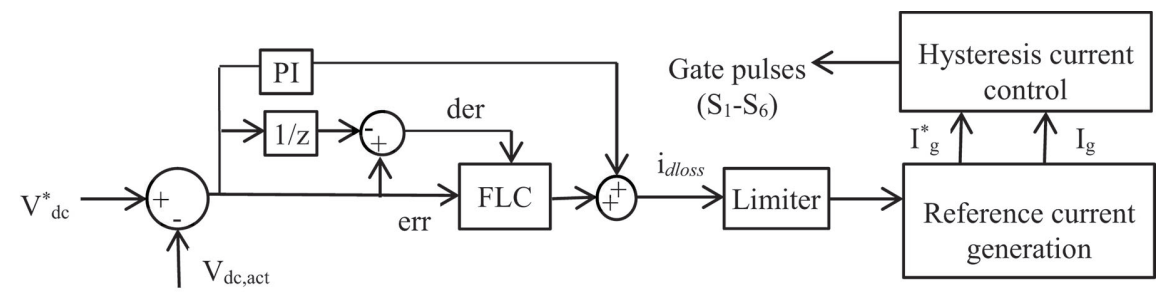

Figure 6 Proposed fuzzy system integrated for DC link voltage regulation. 

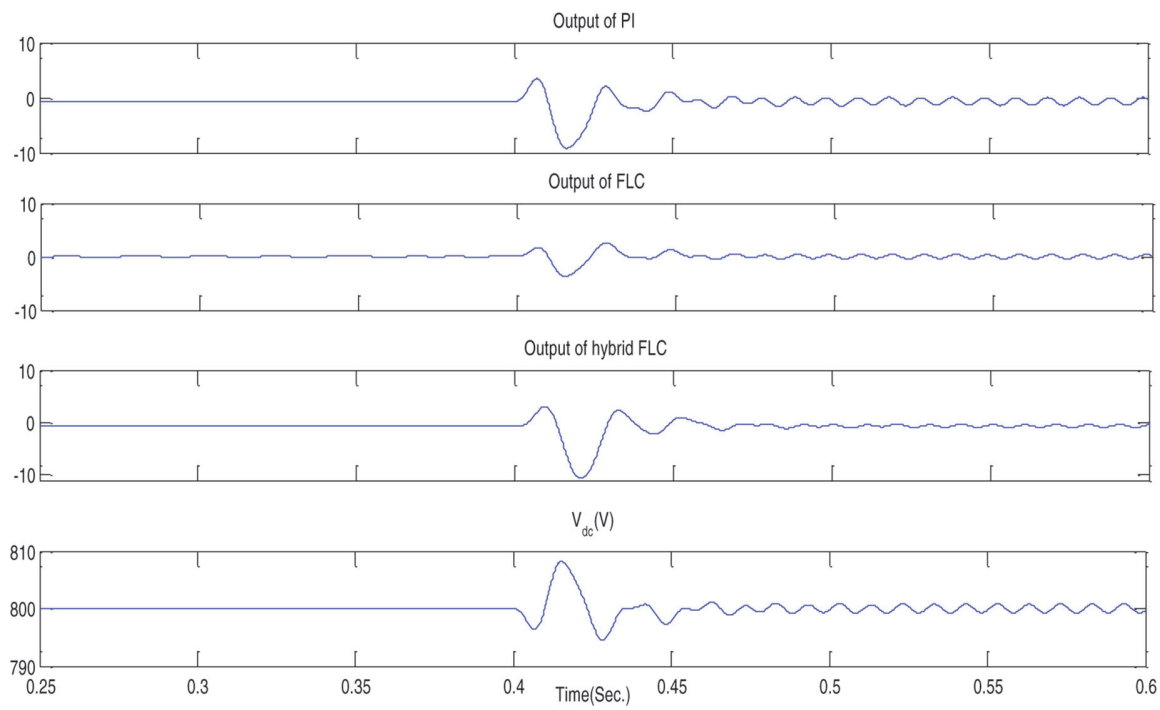

Figure 7 Output of PI, FLC and hybrid FLC controller.

transient conditions. The advantages of FLC and PI controller are obtained by implementing a hybrid Fuzzy-PI controller for DC terminal voltage control. The designed FLC contains seven fuzzy sets for each input and output, triangular membership function, fuzzification is achieved using continuous universe of discourse, Mamdani's 'min' operator is used and centroid method is used for defuzzyfication. The simplified bock diagram of FLC [20] is given in Figure 8 consisting fuzzification interface block knowledge base, decision making logic and defuzzification blocks.

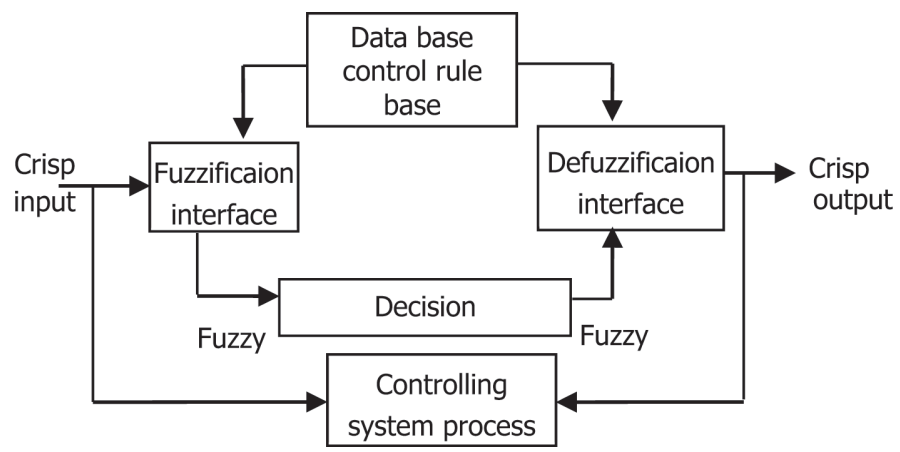

Figure 8 Simplified block diagram of FLC. 


\subsubsection{Design of fuzzy logic rules}

Designing of the fuzzy rules is a crucial part for the proper operation of the controller. The formulation of fuzzy rules is based on the step response of the closed loop system whose shape is shown in the Figure 9. There are two input variables for fuzzy logic controller and one output variable. One input variable is the error (err) between the actual voltage across the capacitor and reference voltage. The second input variable is the change in error (der). The output variable of FLC represents the loss component of the inverter. Time based response has been segregated into different regions depending on error difference (der) and its sign (err).

Four regions are clearly demarcated.

Region 1: for err $>0$ and $\operatorname{der}<0$;

Region 2: for err $<0$ and $\operatorname{der}<0$;

Region 3: for err $<0$ and der $>0$;

Region 4: for err $>0$ and der $>0$.

There are crossing points ( $\mathrm{a} \& \mathrm{~b}$ ): a: change of error from positive to negative value; $b$ : change of error from negative to positive value, there are two peak valleys (p1 \& p2):

$\mathrm{p} 1: \operatorname{der}=0$ and err $<0 ; \mathrm{p} 2:$ der $=0$ and err $>0$

Fuzzy rules can be designed by experience or using knowledge base [14], FLC transforms a linguistic approach into an automatic control approach. Error input (err) and error differential (der) are the feed-in variables of the fuzzy logic controller and output variable are obtained corresponds to current loss calculated below

$$
e r r=V_{d c, a c t}-V_{d c}^{*}
$$

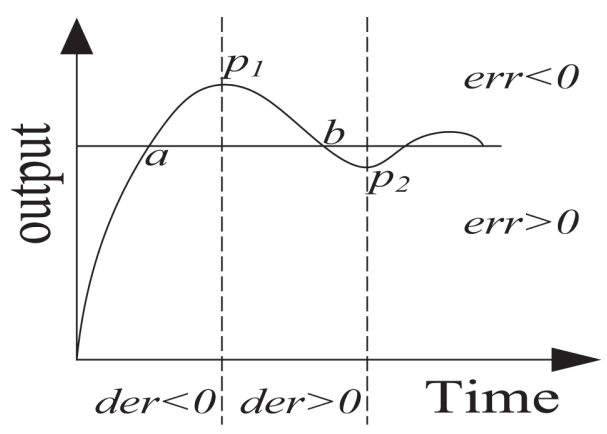

Figure 9 Closed Loop Response of Step Input. 
and,

$$
\operatorname{der}=\operatorname{err}(n)-\operatorname{err}(n-1)
$$

The output of the hybrid FLC is $i_{\text {dloss }}$ corresponds to differential energy ( $\mathrm{d} e_{d c}$ ) needed for a self-supporting DC bus voltage for the VSC and to feed the losses in VSC power circuit. The component $i_{\text {dloss }}$ is given by Equation (20) and differential DC energy $\left(d e_{d c}\right)$ by Equation (21),

$$
\begin{aligned}
i_{d l o s s} & =\frac{2}{3} * \frac{d e_{d c}}{V_{s m} * T_{x}} \\
d e_{d c} & =e_{d c}^{*}-e_{d c}=\frac{1}{2} * C_{d c} *\left[\left(V_{d c, a c t}\right)^{2}-\left(V_{d c}^{*}\right)^{2}\right]
\end{aligned}
$$

$V_{s m}$ is the voltage magnitude of the system and $T_{x}$ is the one sixth of the time constant of the supply voltage and given by Equation (22)

$$
T_{x}=\frac{1}{6} * T_{s}=\frac{1}{6} * \frac{1}{f_{s}}
$$

The trilateral waveform is utility of vector $\mathrm{x}$ and it depends upon three parameter $\mathrm{p} \mathrm{q} \mathrm{r}$ which are scalar quantity this can be represent by Figure 10. Values of $p, q$ and $r$ can be refer from Figure 11, i.e. membership function (MF).

$$
\lambda_{P}(x)=\max \left(\min \left(\frac{x-p}{q-p}, \frac{r-x}{r-q}\right), 0\right)
$$

All MFs for the FLC inputs and the output are distributed in the range of $[-1,1]$ having a shape of symmetric triangles. These triangular membership functions overlap each other as shown in Figure 11. The MFs are denoted as NL, NM, NS, Z, PS, PM, PL, which stands for Negative Large, Negative Medium, Negative Small, Zero, Positive Small, Positive Medium,

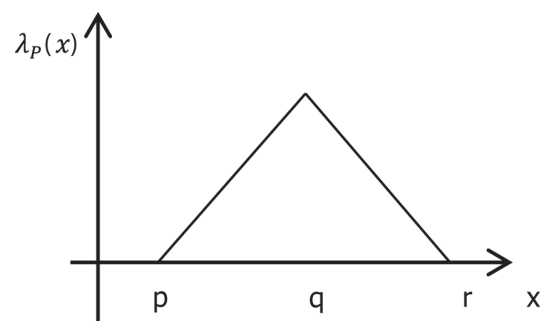

Figure 10 Triangular membership function. 


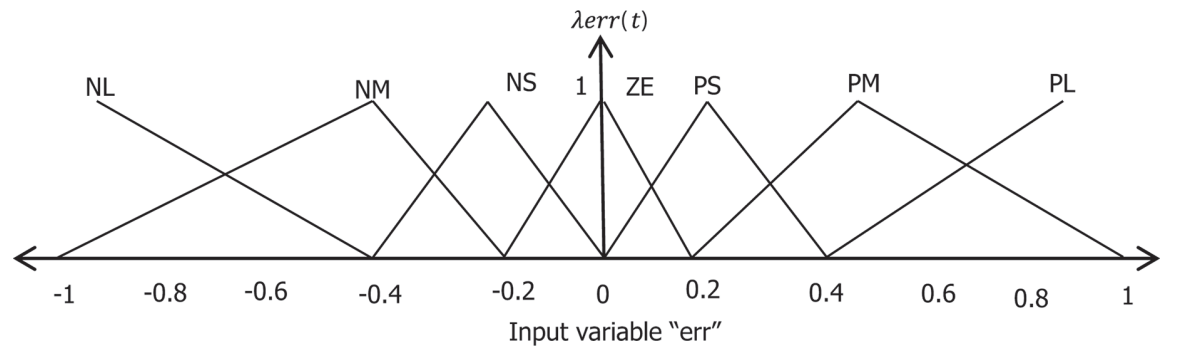

(a)

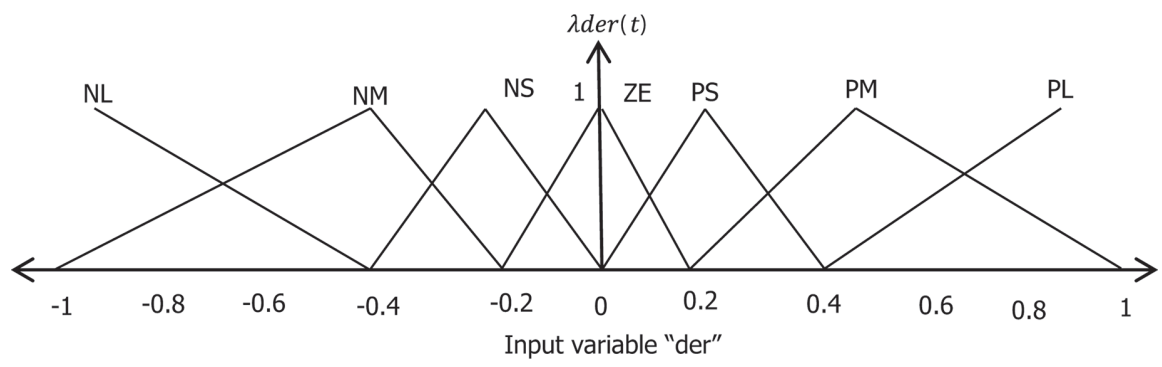

(b)

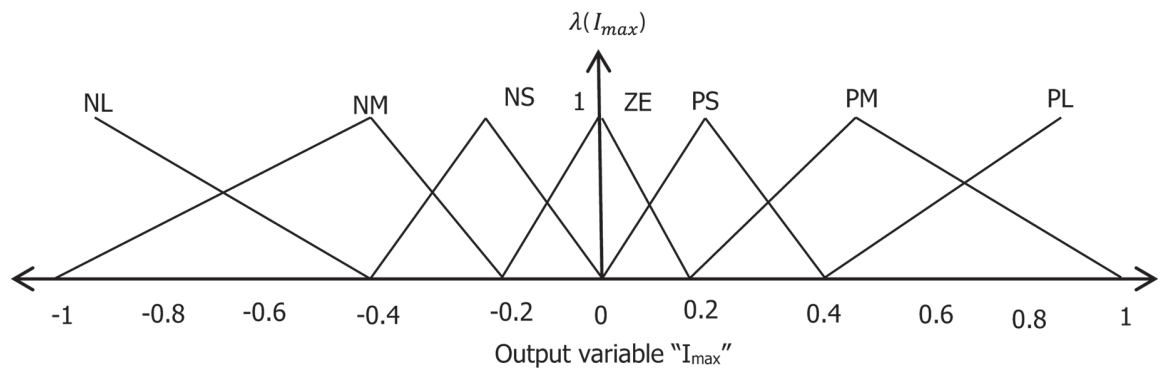

(c)

Figure 11 (a) Input variable error "err" triangular membership function, (b) Input variable change in error "der" normalized triangular function and (c) Output variable $I_{\text {max }}$ normalized triangular function.

Positive Big respectively. The two dimensional rule base, to compute DC energy loss current component is shown in Table 1. The control rules are based on the characteristics of the response if the deviation of the DC link voltage from the set reference point is quite large, then the output current component has a relatively large value to pull it back to the reference set point as compared to the case when error is relatively small. 
Table 1 Fuzzy rule base

\begin{tabular}{llllllll}
\hline der $\backslash$ err & NL & NM & NS & Z & PS & PM & PL \\
\hline NL & NL & NL & NL & NL & NM & NS & Z \\
\hline NM & NL & NL & NL & NM & NS & Z & PS \\
\hline NS & NL & NL & NM & NS & Z & PS & PM \\
\hline Z & NL & NM & NS & Z & PS & PM & PL \\
\hline PS & NM & NS & Z & PS & PM & PL & PL \\
\hline PM & NS & Z & PS & PM & PL & PL & PL \\
\hline PL & Z & PS & PM & PL & PL & PL & PL \\
\hline
\end{tabular}

\subsection{VSC Control through Power Balance Control Theory}

Complete system control diagram for proposed topology is depicted in Figure 12. The implementation of power balance control theory is based on templates generation. This control is used for compensation, synchronization depends upon the generated templates. These templates are computed to be in phase with the grid and to control active power these templates are multiplied to d-axis components.

The value of the voltage at the junction of load, grid and VSC, which is known as point of common coupling (PCC) and the terminal voltage at this point $\mathrm{V}_{\mathrm{tpcc}}[12]$ is calculated as

$$
\mathrm{V}_{\mathrm{tpcc}}=(2 / 3)^{\frac{1}{2}}\left(\mathrm{~V}_{\mathrm{ga}}^{2}+\mathrm{V}_{\mathrm{gb}}^{2}+\mathrm{V}_{\mathrm{gc}}^{2}\right)
$$

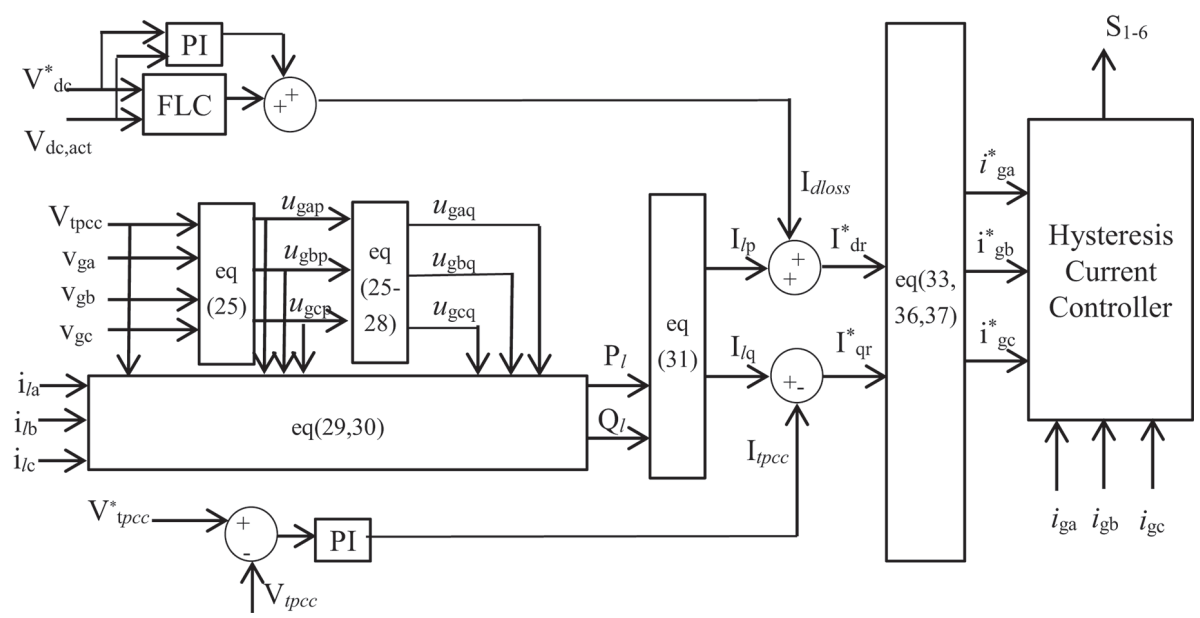

Figure 12 Complete system control diagram of proposed scheme. 
In phase unit vector component of load voltage can be estimated by

$$
\mathrm{u}_{\text {gap }}=\mathrm{V}_{\mathrm{ga}} / \mathrm{V}_{\mathrm{tpcc}} ; \mathrm{u}_{\mathrm{gbp}}=\mathrm{V}_{\mathrm{gb}} / \mathrm{V}_{\mathrm{tpcc}} ; \mathrm{u}_{\mathrm{gcp}}=\mathrm{V}_{\mathrm{gc}} / \mathrm{V}_{\mathrm{tpcc}}
$$

where $\mathrm{V}_{\mathrm{ga}}, \mathrm{V}_{\mathrm{gb}}, \mathrm{V}_{\mathrm{gc}}$ are grid voltage of phase $\mathrm{a}, \mathrm{b}, \mathrm{c}$ respectively. The quadrature templates are utilized for reactive power compensation. The unit vectors in quadrature with supply voltage can be derived as,

$$
\begin{aligned}
& u_{g a q}=\left(-u_{g b p}+u_{g c p}\right) / \sqrt{ } 3 \\
& u_{g b q}=\frac{u_{g a p}}{\sqrt{2}}+\frac{\left(u_{g b p}-u_{g c p}\right)}{\sqrt{6}} \\
& u_{g c q}=\frac{\left(u_{g b p}-u_{g c p}\right)}{\sqrt{6}}-\frac{u_{g a p}}{\sqrt{2}}
\end{aligned}
$$

The real time active power and reactive power of the load has two components. The first component corresponds to the DC value while the other component is oscillating in nature and calculated as

$$
\begin{aligned}
& \mathrm{P}_{l}=\mathrm{V}_{\mathrm{tpcc}} *\left(\mathrm{u}_{\mathrm{gap}} * i_{l a}+\mathrm{u}_{\mathrm{gbp}} * i_{l b}+\mathrm{u}_{\mathrm{gcp}} * i_{l c}\right) \\
& \mathrm{Q}_{l}=\mathrm{V}_{\mathrm{tpcc}} *\left(u_{g a q} * i_{l a}+u_{g b q} * i_{l \mathrm{~b}}+\mathrm{u}_{\mathrm{gcq}} * i_{l c}\right)
\end{aligned}
$$

where $i_{l a}, i_{l b}, i_{l c}$ are load current of phase a, b, c respectively. To extract active power component of load $\mathrm{P}_{1}$ is made to pass through LPF (low pass filter). Active component of load can be represent by

$$
\mathrm{I}_{l \mathrm{p}}=\left(\frac{2}{3}\right)\left(\frac{\mathrm{P}_{l}}{\mathrm{~V}_{\mathrm{tpcc}}}\right)
$$

where $\mathrm{P}_{l}$ is average component of real power of load and is obtained by filter through LPF. The VSC is controlled in such manner that it provides power factor correction, load balancing and harmonic reduction. The control is designed to ensure that active part of the load power is provided by FC (if available) and supply provides the power loss inside the converter. In this paper hybrid FLC controller is designed to set the voltage of DC link at mentioned reference voltage and delivers the active power. The magnitude of d-component of reference currents can be expressed as:

$$
\mathrm{I}_{d r}^{*}=\mathrm{I}_{l \mathrm{p}}+\mathrm{I}_{\text {dloss }}
$$

and the active real power in phase component of reference currents is calculated as:

$$
i_{\mathrm{gad}}^{*}=\mathrm{I}_{d r}^{*} * \mathrm{u}_{\mathrm{gap}} ; \quad i_{g b d}^{*}=i_{d r}^{*} * \mathrm{u}_{\mathrm{gbp}} ; \quad \mathrm{i}_{\mathrm{gcd}}^{*}=I_{d r}^{*} * \mathrm{u}_{\mathrm{gcp}}
$$


Reactive component of load current is estimated as:

$$
\mathrm{I}_{l r}=\left(\frac{2}{3}\right)\left(\frac{\mathrm{q}_{l}}{\mathrm{~V}_{\mathrm{tpcc}}}\right)
$$

It is desired to obtain zero voltage regulation at junction of load, grid and FC generation system. This condition can be obtained by the subtracting the output of PI realised over the PCC voltage from load reactive Power component (35). PI controller is used to regulate the voltage at the junction of load, grid and FC generation system. Inputs of PI controller are actual PCC voltage and reference voltage. The second controller is not required and hence terminated it used only for active power flow component of current is terminated in power factor correction mode. The value of reactive element of the reference current is represent as:

$$
\mathrm{I}_{q r}^{*}=\mathrm{I}_{l r}-\mathrm{I}_{\mathrm{tpcc}}
$$

where $\mathrm{I}_{\mathrm{tpcc}}$ represents the output of the PI controller used for AC voltage regulation. Reactive power components of reference grid currents are

$$
i_{g a q}^{*}=u_{g a q} * \mathrm{I}_{q r}^{*} ; \quad i_{g b q}^{*}=u_{g b q} * \mathrm{I}_{q r}^{*} ; \quad i_{\mathrm{gcq}}^{*}=u_{g c q} * \mathrm{I}_{q r}^{*}
$$

Three phase reference currents for the grid can be estimated as

$$
i_{g a}^{*}=i_{g a q}^{*}+i_{g a d}^{*} ; \quad I_{g c}^{*}=i_{g c q}^{*}+i_{g c d}^{*} ; \quad i_{g a}^{*}=i_{g b q}^{*}+i_{g b d}^{*}
$$

Obtained generated reference current and measured grid currents are passed through hysteresis current controller (HCC) and the HCC controls the VSC output current. To obtaining the gating signals of VSC, HCC is used. Obtained currents are reference current and actual generated grid current has to follow the generated reference to control the VSC these currents within a definite hysteresis band to generate suitable gate pulses.

\section{Simulation Results}

Performance evaluation of grid interfaced FC based micro grid system is presented in this section. Evaluation is presented in terms of following parameters: DC link voltage $\left(\mathrm{V}_{\mathrm{dc}}\right)$, grid voltage $\left(\mathrm{V}_{\mathrm{g}}\right)$, grid current $\left(\mathrm{I}_{\mathrm{g}}\right)$, load active and reactive power demand $\left(\mathrm{P}_{\mathrm{L}}, \mathrm{Q}_{\mathrm{L}}\right)$, active and reactive power delivered by $\mathrm{FC}$ are $\mathrm{P}_{\mathrm{FC}}, \mathrm{Q}_{\mathrm{FC}}$ respectively and power from the grid $\left(\mathrm{P}_{\mathrm{g}}\right)$. The analysis of the system is done for linear, nonlinear load and load balancing under power factor correction mode and voltage regulation mode. The FC 
generation system capacity is $3 \mathrm{~kW}$, DC voltage is regulated at $800 \mathrm{~V}, \mathrm{AC}$ voltage is regulated at $340 \mathrm{~V}$ and detailed parameters of the system are listed in the Appendix.

\subsection{Operation under Power Factor Correction Mode}

Performance evaluation of the proposed system is tested for linear load and nonlinear load as depicted in Figure 13. At 0.4s the load demand is switched to nonlinear load (Diode Bridge with $50 \Omega, 100 \mathrm{mH}$ ). It can be observed from the Figure 13 that DC link is regulated at $800 \mathrm{~V}$ by FLC controller, DC link voltage is regulated to be constant under dynamic load changes. The system achieves unity power factor at the grid side which is also inferred from the voltage and current in-phase relationship depicted in Figure 13. The perturbation in $\mathrm{Vdc}$ is $\sim 8$ Volt i.e. $1 \%$ and recovered within one cycle. Due to sudden change of load; power transfer through lines gets affected and these changes generate disturbances in DC link voltage. However, it is necessary

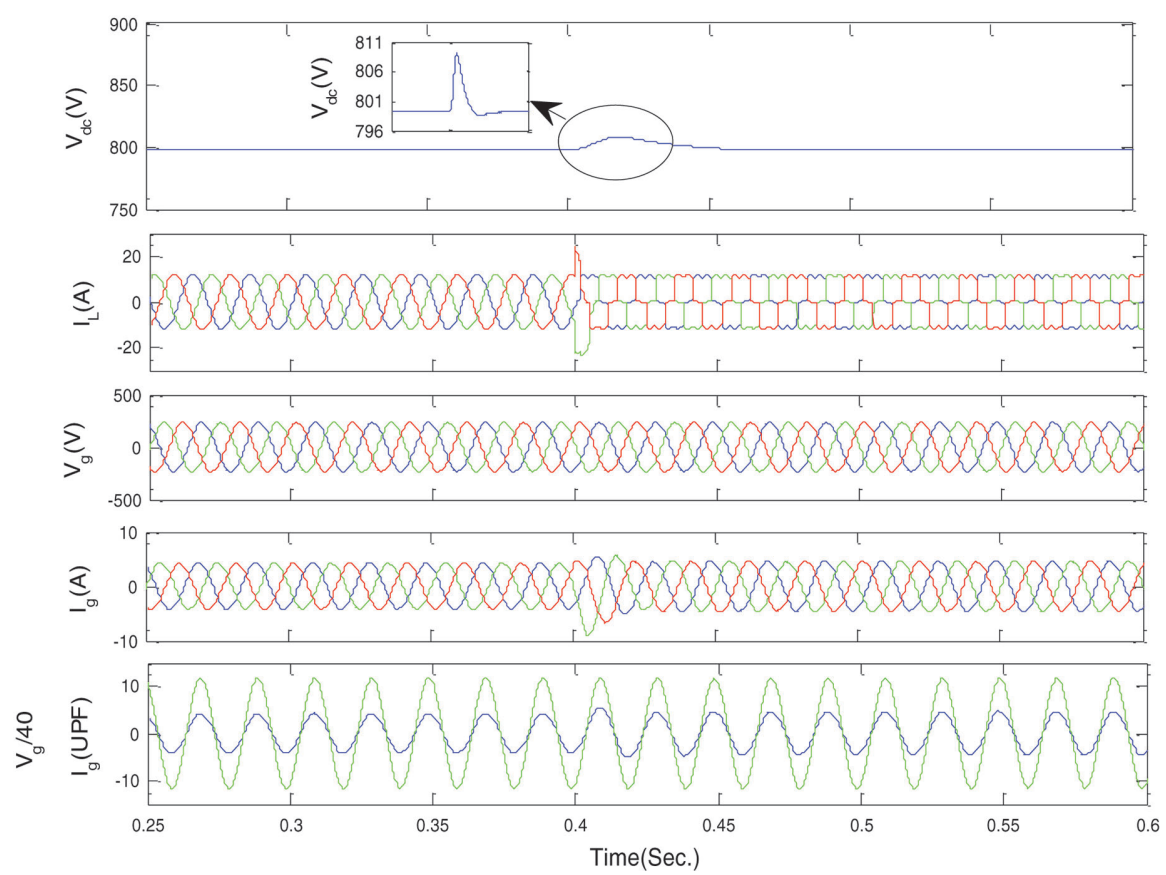

Figure 13 System performance for linear load and nonlinear load for power factor correction. 
to ensure reliable and steady operation using a suitable controller. Incorporating a controller which can maintain a constant voltage level under major disturbances such as a sudden change in load becomes mandatory. The paper discusses the design, analysis and performance of H-FLC for fuel cell based system. The results demonstrate the improvement in stability and performance of system.

The Power distribution between the FC and utility with the change of load is shown in Figure 14 under power correction mode. For time duration up to $0.4 \mathrm{~s}$, the connected load is linear ( $6 \mathrm{kVA}$ with $0.8 \mathrm{pf}$ ), at $\mathrm{t}=0.4 \mathrm{~s}$ linear load is disconnected and nonlinear load is connected. It is observed that the active power demand ( $6 \mathrm{~kW}$ with $0.8 \mathrm{pf}$ ) is more than the FC generation $(3 \mathrm{~kW})$ so grid supplies $3 \mathrm{~kW}$ to meet the total real power requirement of the load. The reactive power demand of the load is completely met by the voltage source converter which has FC connected DC link under power factor correction mode. The perturbation in $\mathrm{P}_{\mathrm{g}}$ is large because the performance of the controller is test under a major load change. The simulation results under this change however show the DC link control is well settled and the controller is properly designed and functioning well. The steady state conditions are observed within 1 cycle. $\mathrm{P}_{\mathrm{g}}$ is become $3.3 \mathrm{~kW}$ after perturbation to meet the increased load requirement. FC power is settled again at $3 \mathrm{~kW}$ after disturbances.

Figure 15 shows system performance under power factor correction mode for linear unbalanced load. An unbalanced three-phase load (phase $\mathrm{A}=500 \Omega$, phase $\mathrm{B}=880 \Omega$, phase $\mathrm{C}=1000 \Omega$ ) is connected to the system for performance analysis, at $0.4 \mathrm{~s}$ load is reduced to its half value. The grid supply current is still balanced and sinusoidal under transients which confirm the effectiveness of the control algorithm and DC link voltage is maintained at $800 \mathrm{~V}$ under all the condition by the DC link controller action. It can be observed that sudden power shoot is present during load change this is occur due to sudden change of load, it settled in very short time due to effective control scheme.

Figure 16 shows system power allocation under unbalanced load conditions, total power requirement of the load is $1 \mathrm{~kW}$, whereas FC generation system generates $3 \mathrm{~kW}$ so surplus $2 \mathrm{kw}$ power is supplied to the grid, negative value of power for grid indicates power is delivered to the grid. At $0.4 \mathrm{~s}$ load demand reduced to its half value $(0.5 \mathrm{~kW})$ and this surplus power also fed to the grid and power allocation of the system is as per load requirement. 
148 S. Gupta et al.
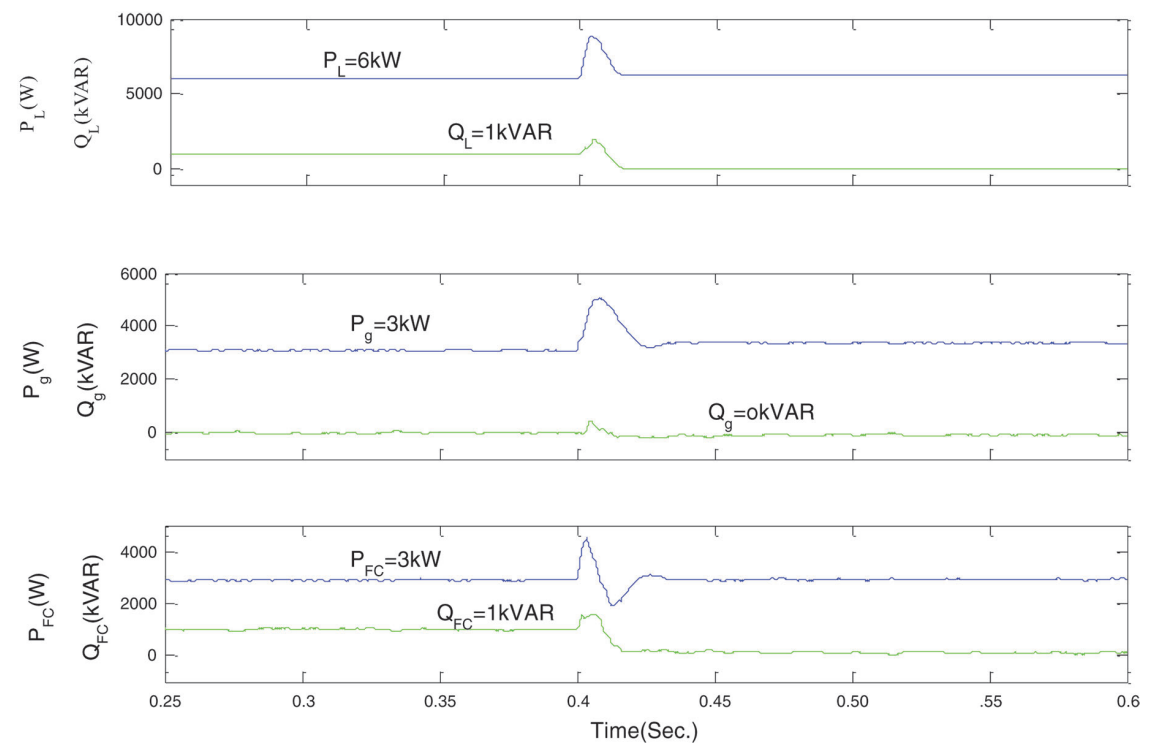

Figure 14 Power allocation for linear and nonlinear load under power factor correction mode.
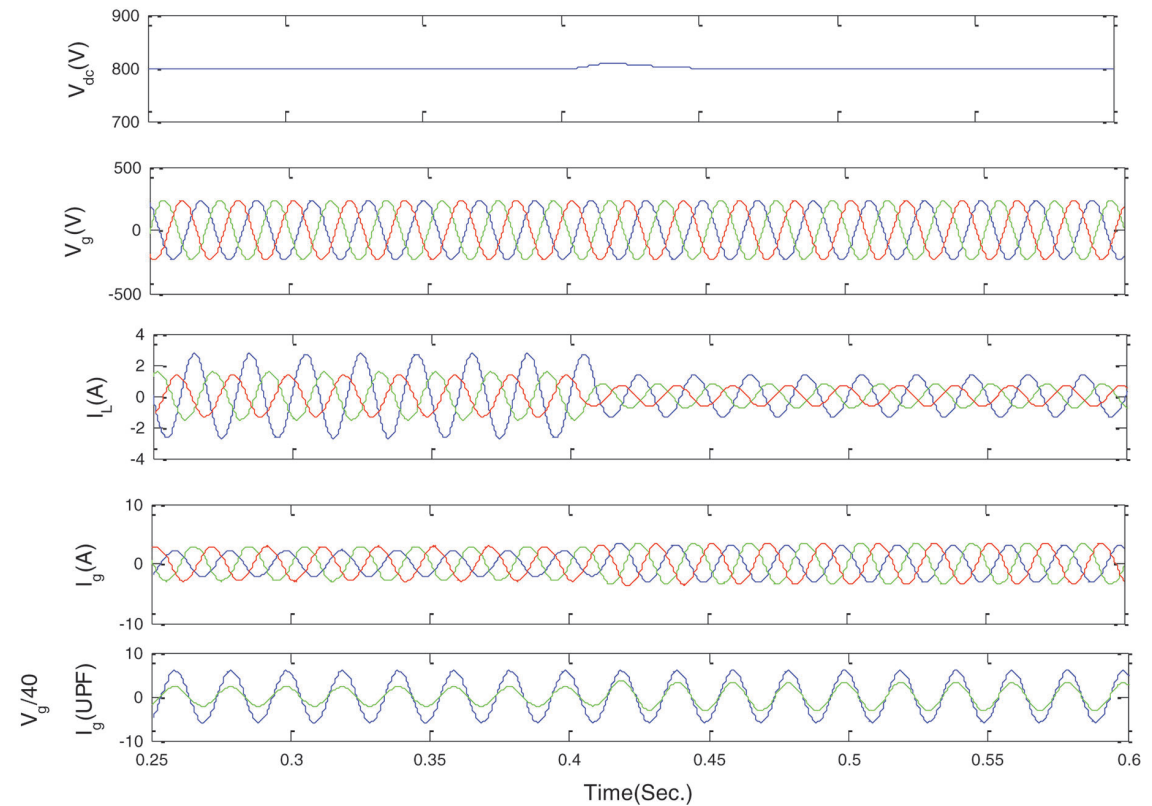

Figure 15 System performance for unbalanced load demand under power factor correction mode. 

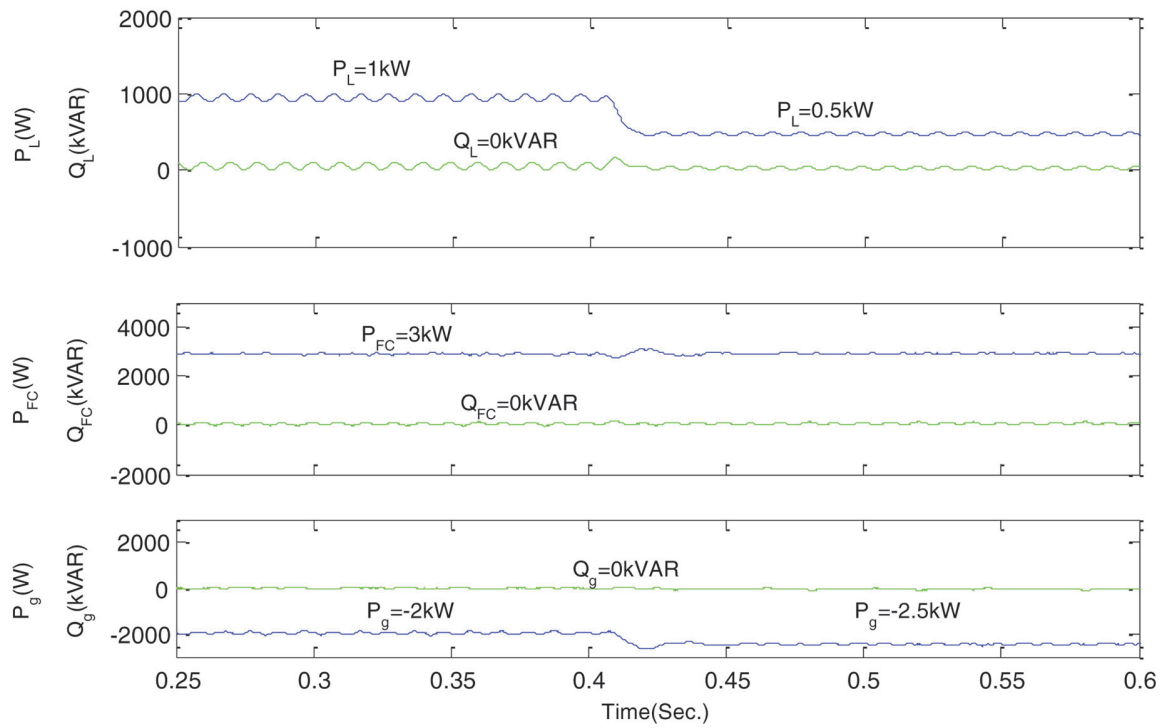

Figure 16 Power allocation for unbalanced under power factor correction mode.

\subsection{System Performance under Voltage Regulation Mode}

Figure 17 demonstrates the performance of GCFC micro grid system under voltage regulation mode, PCC voltage is maintained at $340 \mathrm{~V}$ during the performance. Voltage regulation is achieved via a second controller which is PI controller and the terminal voltage is maintained at $340 \mathrm{~V}$ and DC link is regulated at $800 \mathrm{~V}$ by hybrid FLC controller. Figure 18 shows power distribution between grid and FC generation. Time duration up to $0.4 \mathrm{~s}$ load demand is linear 6kVA with $0.8 \mathrm{pf}$, since active power demand is more than the FC generation so this will be supplied through FC $(3 \mathrm{~kW})$ and grid $(3 \mathrm{~kW})$ together, reactive power demand is supplied through the FC generation system. At $0.4 \mathrm{~s}$ the load demand is switched to nonlinear load (Diode Bridge with $50 \Omega, 0.5 \mathrm{mH}$ ) and no active power requirement in this load condition.

Figure 19 shows the performance of the system under voltage regulation mode where the PCC voltage is regulated at $340 \mathrm{~V}$. PI controller is designed and tuned to regulate $\mathrm{PCC}$ voltage to its reference value. An unbalanced threephase load (phase $\mathrm{A}=35 \Omega$, phase $\mathrm{B}=44 \Omega$, phase $\mathrm{C}=50 \Omega$ ) is coupled to the system. The grid supply current is balanced and sinusoidal and shows the effectiveness of the proposed system, the DC link voltage is maintained at 

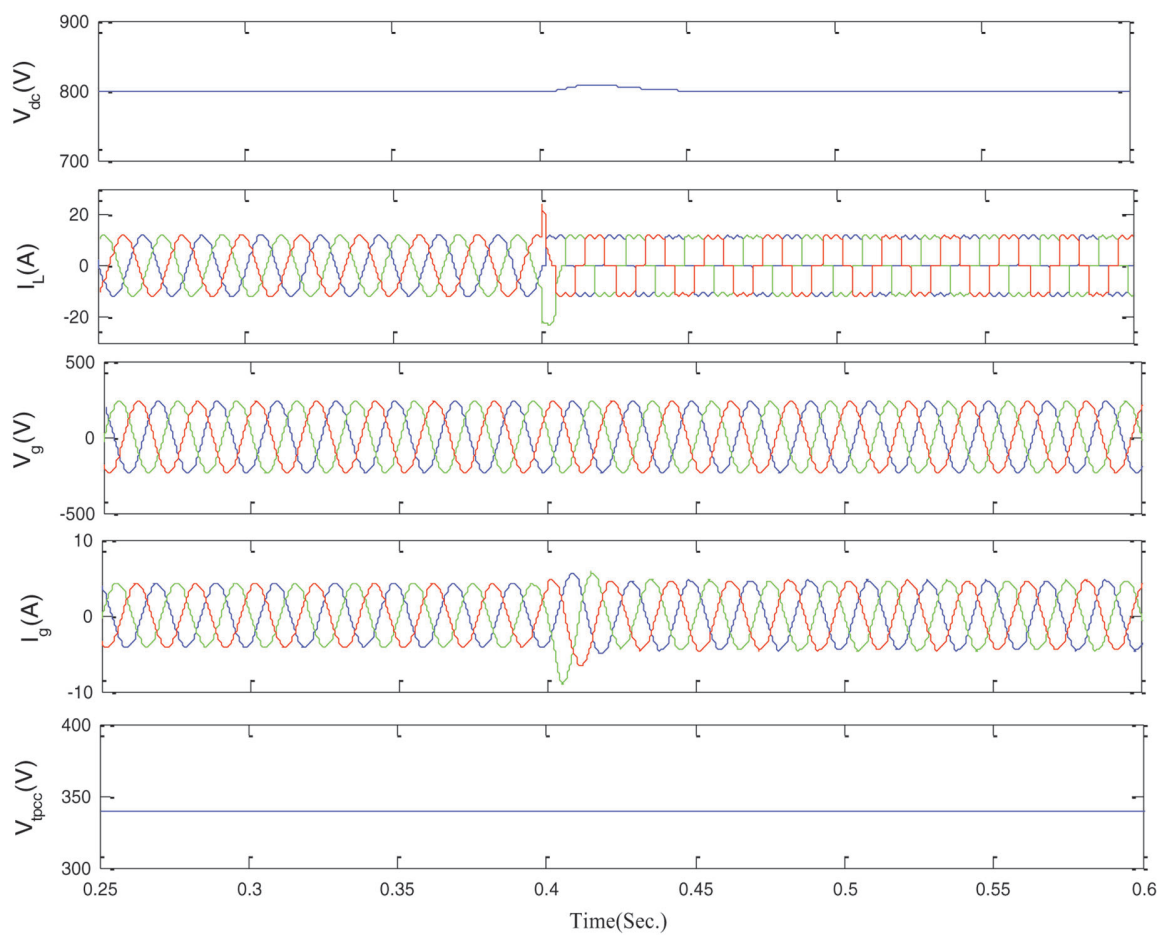

Figure 17 System performance for linear and nonlinear load demand under voltage regulation with sudden load changes introduced at $\mathrm{t}=0.4 \mathrm{~s}$.

$800 \mathrm{~V}$ by the controller action. Power demand and its allocation of the system same as in Power factor correction mode Figure 16.

Figure 20 represents the load current harmonics for nonlinear load which is $30.64 \%$. The performance comparison of proposed system for SRFT [21] and PBCT algorithms on the basis of THD analysis under nonlinear load conditions is shown in Figure 21. Figure 21(a) shows that THD for PBCT of grid supply currents with hybrid FLC Controller is $1.35 \%$ and Figure 21(b) depicts that THD using PBCT with PI controller is 1.43\%; Figure 21(c) shows THD for SRFT method with FLC using Matlab simulation is $1.6 \%$. From the THD analysis we can conclude that the PBCT method with hybrid FLC demonstrated superior performance. 

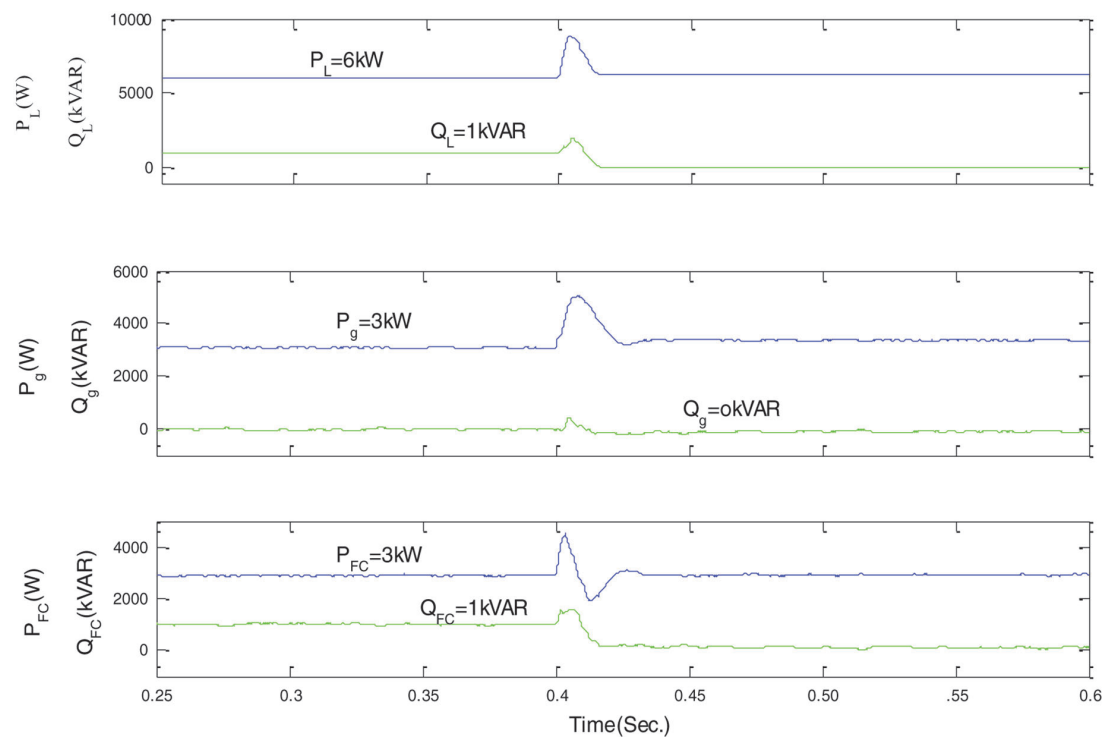

Figure 18 Power allocation for linear and nonlinear load under voltage regulation mode.
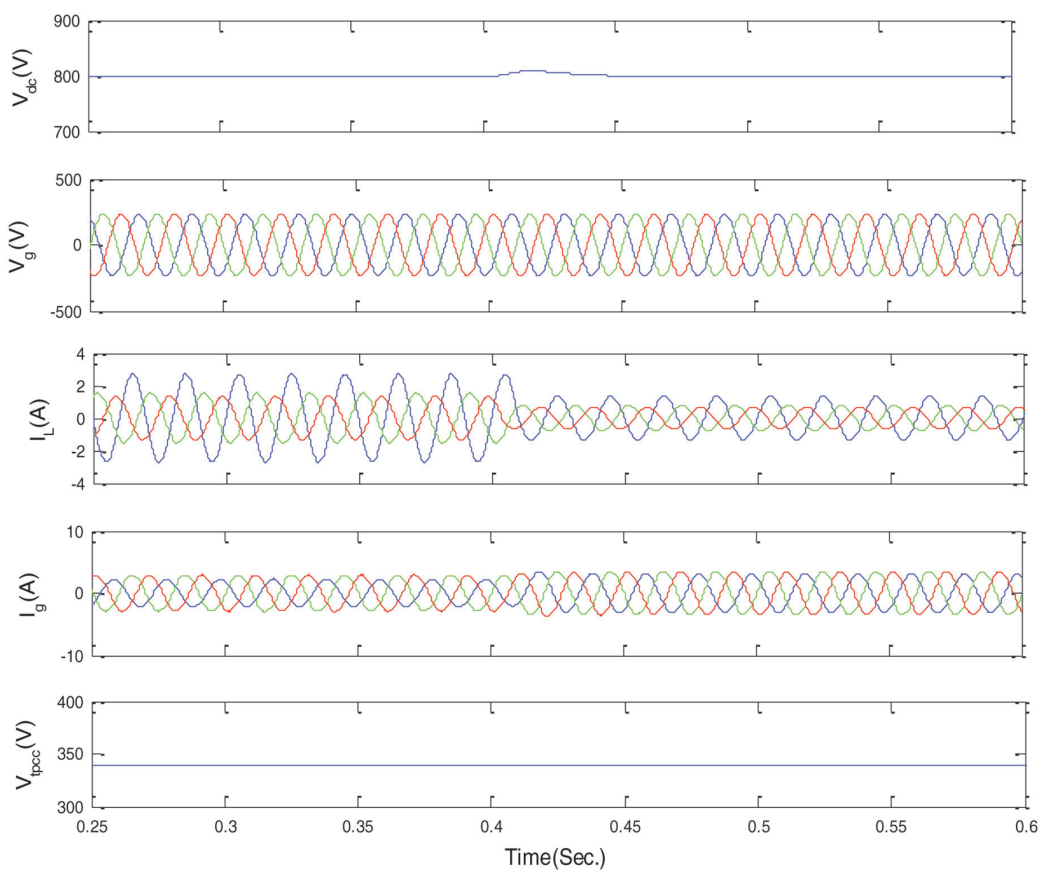

Figure 19 System performance for unbalance load demand under voltage regulation. 

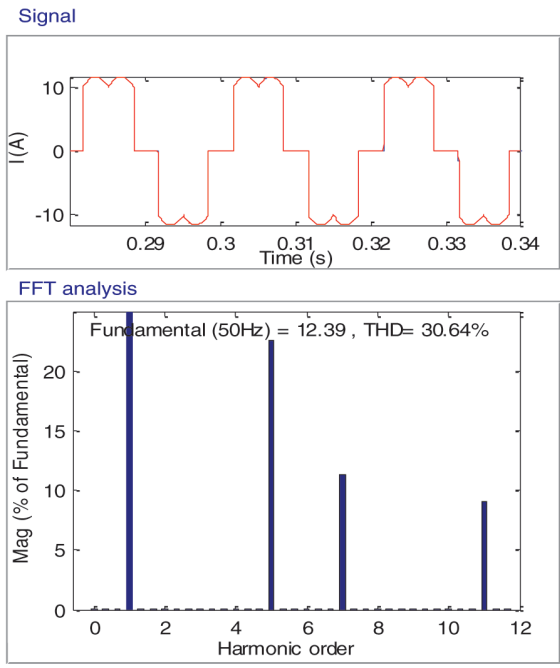

Figure 20 Harmonic spectrum of nonlinear load.
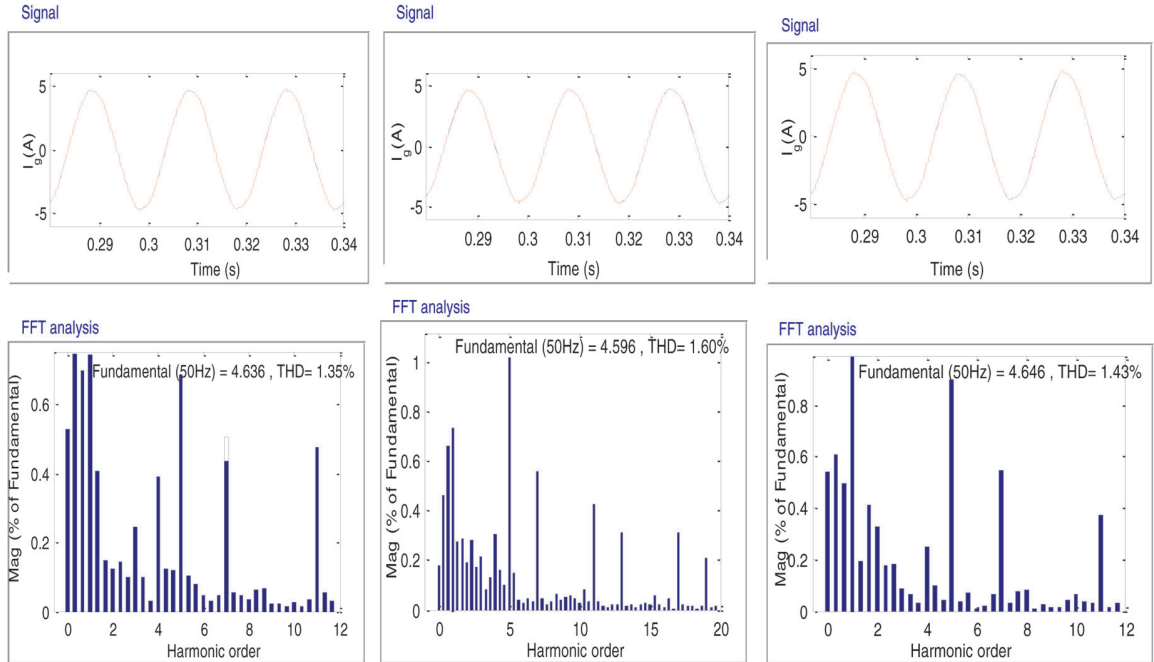

(a)

(b)

(c)

Figure 21 Grid current Harmonic spectrum (a) Hybrid FLC based PBT (b) PI based PBT and (c) FLC based SRFT. 


\section{Conclusions}

This paper present detail of design, simulation and modelling of $3 \mathrm{~kW}$ FC system interconnected to grid. The solid oxide fuel cell with power conditioning devices is integrated to the grid via an LCL filter to connect the SOFC to the grid. Power conditioning unit contains a DC-DC boost converter, a DC-AC inverter and LCL filter. The proposed model can work as a fuel cell based micro-grid. Further, alternative RES may also be connected without change in control architecture. Designing and superior performance of LCL filter is over LC and L filter is also demonstrated successfully. Indirect current control hybrid FLC based PBCT is proposed for inverter control which has shown superior results over FLC based SRFT and PI based PBCT. The grid current references are created through in phase and quadrature phase templates which are generated by the PBCT control algorithm. In proposed design, two controllers are considered where hybrid FLC keeps DC link voltage at fixed value and PI controller is used to PCC voltage control. Result shows satisfactory responses of SOFC generation system to meet the desired performance of the proposed scheme in terms of voltage regulation, active power and reactive power allocation, load balancing and suppression harmonic suppression. The system is tested under linear load, unbalanced load and nonlinear load conditions and demonstrates satisfactory performance. Further, the resultant THD complies with IEEE standards and requirements.

\section{Appendix}

Fuell cell Parmeter: $\mathrm{r}=32813 * 10^{-8} \Omega$, Response time for oxygen flow $=78.3 \mathrm{~s}$, Response time for hydrogen flow $=26.1 \mathrm{~s}, \mathrm{Ko}_{2}=2.52 * 10^{-3}$ $(\mathrm{kmol} / \mathrm{atm}), \mathrm{K}_{\mathrm{H} 2 \mathrm{O}}=2.81 * 10^{-4}(\mathrm{kmol} / \mathrm{atm}), \mathrm{K}_{\mathrm{H} 2}=8.43 * 10^{-4}(\mathrm{kmol} / \mathrm{atm})$, $\mathrm{T}=1273 \mathrm{~K}, \mathrm{~F}=96487 \mathrm{C} / \mathrm{kmol}, \mathrm{R}=8314 \mathrm{~J} / \mathrm{kmol} \mathrm{K}$, Ideal standard potential $=1.18 \mathrm{~V}, \mathrm{~N}=450, \mathrm{~K}_{\mathrm{r}}=0.842 * 10^{-6} \mathrm{kmol} / \mathrm{s}(\mathrm{A})$

Other parameters: $\mathrm{L}($ Boost converter $)=1.5 \mathrm{mH}, \mathrm{C}($ Boost converter $)=$ $250 \mu \mathrm{F}$, AC line voltage $=415 \mathrm{~V}, 50 \mathrm{~Hz}$, Modulation index $=0.9$, Line Impedance $=(\mathrm{Rs}=.05 \Omega, \mathrm{Ls}=1 \mathrm{mH}), \mathrm{L}_{\mathrm{a}}($ Filter $)=1.2 \mathrm{mH}, \mathrm{L}_{\mathrm{b}}($ Filter $)=0.96 \mathrm{mH}$ $\mathrm{C}($ Filter $)=1000 \mu \mathrm{F}, \mathrm{R}($ Filter $)=10 \Omega, \mathrm{DC}$ link capacitor $=1500 \mu \mathrm{F}$.

\section{Acknowledgement}

The authors are grateful to the Department of Science and Technology, Government of India for the Sponsored Project (EMR/2016/001874). 


\section{References}

[1] Sekhar, P. C., and Mishra, S. (2014). Sliding mode based feedback linearizing controller for grid connected multiple fuel cells scenario. Int. J. Electr. Power Energy Syst. 60, 190-202.

[2] Blaabjerg, F., Teodorescu, R., Liserre, M., and Timbus, A. V. (2006). Overview of control and grid synchronization for distributed power generation systems. IEEE Trans. Ind. Electron. 53.5, 1398-1409.

[3] Jin Woo, J. (2005). Modeling and Control of Fuel Cell Based Distributed Generation Systems. Dissertation thesis, Ohio State University, Columbus, $\mathrm{OH}$.

[4] Jin-Woo, J., and Keyhani, A. (2007). Control of a fuel cell based Z-source converter. IEEE Trans. Energy Convers. 22.2, 467-476.

[5] Khan, M. J., and Iqbal, M. T. (2005). Dynamic modeling and simulation of a fuel cell generator. Wiley Fuel Cells, 5, 97-104.

[6] Ali, K., and Irmak, E. (2016). "Modeling and simulation of a static VAR compensator based on FC-TCR," in Proceedings of the IEEE International Conference on Renewable Energy Research and Applications (ICRERA), Birmingham.

[7] Malla, S. G., and Vadrevu, R. K. (2016). "Novel controller scheme for grid connected fuel cell," in Proceedings of the IEEE International Conference on Electrical, Electronics, and Optimization Techniques (ICEEOT), Chennai.

[8] Akagi, H., Kanazawa, Y., and Nabae, A. (1984). Instantaneous reactive power compensators comprising switching devices without energy storage component. IEEE Trans. Ind. Appl. 20, 625-631.

[9] Akagi, H., Watanabe, E. H., and Aredes, M. (2007). Instantaneous Power Theory and Applications to Power Conditioning. Piscataway, NJ: IEEE Press.

[10] Chandra, A., Singh, B., and Singh, B. N. (2000). An improved control algorithm of shunt active filter for voltage regulation, harmonic elimination, power-factor correction, and balancing of nonlinear loads. IEEE Trans. Power Electron. 15, 495-507.

[11] Almeida, P. M., Barbosa, P. G., Duarte, J. L., and Ribeiro, P. F. (2017). Comprehensive synchronous reference frame discrete-time modelling of a grid-connected PV for fast DC-side voltage control. Electric Power Syst. Res. 150, 162-168.

[12] Xavier, L. S., Cupertinob, A. F., de Resendea, J. T., Mendesc, V. F., and Pereiraa, H. A. (2017). Adaptive current control strategy for harmonic 
compensation insingle-phase solar inverters. Electric Power Syst. Res. $142,84-95$.

[13] Singh, B., and Kumar, S. (2010). "Modified power balance theory for control of DSTATCOM," in Proceedings of the Joint International Conference on Power Electronics, Drives and Energy Systems (PEDES) \& 2010 Power India (New Delhi: IEEE).

[14] Zue, A. O., and Chandra, A. (2006). "Simulation and stability analysis of a $100 \mathrm{~kW}$ grid connected LCL photovoltaic inverter for industry," in Proceedings of the IEEE Power Engineering Society General Meeting, Montreal, QC.

[15] Liserre, M., Blaabjerg, F., and Hansen, S. (2005). Design and control of an LCL-filter-based three-phase active rectifier. IEEE Trans. Ind. Appl. 41, 1281-1291.

[16] Cha, H., and Vu, T.-K. (2010). "Comparative analysis of low-pass output filter for single-phase grid-connected Photovoltaic inverter," in Proceeding of the IEEE Applied Power Electronics Conference and Exposition (APEC), Palm Springs, CA.

[17] Benyamina, A., Moulahoum, S., Colak, I., and Bayindir, R. (2016). "Hybrid fuzzy logic-artificial neural network controller for shunt active power filter," in Proceedings of the Renewable Energy Research and Applications (ICRERA), (Birmingham: IEEE).

[18] Xavier, L. S., et al. (2017). Adaptive PI controller to voltage regulation in power systems: STATCOM as a case study. Electr. Power Syst. Res. 142, 84-95.

[19] Bhende, C. N., Mishra, S., and Malla, S. G. (2011). Permanent magnet synchronous generator-based standalone wind energy supply system. IEEE Trans. Sustain. Energy 2.4, 361-373.

[20] Mikkili, S., and Panda, A. K. (2012). Real-time implementation of PI and fuzzy logic controllers based shunt active filter control strategies for power quality improvement. Int. J. Electr. Power Energy Syst. 43.1, 1114-1126.

[21] Gupta, S., Garg, R., and Singh, A. (2015). "TS-fuzzy based controller for grid connected PV system," in Proceedings of the Annual IEEE India Conference (INDICON), New Delhi, 1-6.

[22] Gupta, S., Garg, R., and Singh, A. (2016). "Grid integrated PMSG based wind energy system: modelling, control and simulation," in Proceedings of the 1st IEEE International Conference on Power Electronics, Intelligent Control and Energy Systems (ICPEICES-2016), New Delhi. 


\section{Biographies}

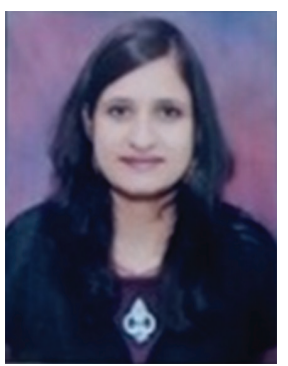

Shikha Gupta is a Ph.D. student at the Delhi Technological University. She received her B.E. in Electrical Engineering from OIST, RGPV, Bhopal, M.P. in 2003. Then after obtained her Masters Degree in Engineering from Rajiv Gandhi Proudyogiki Vishwavidyalaya, Bhopal, Madhya Pradesh, in the year 2005. Currently, she is research scholar in DTU, Delhi, India. Her main areas of expertise are modelling and simulation of power electronic converters, power quality, grid integration, renewable energy.

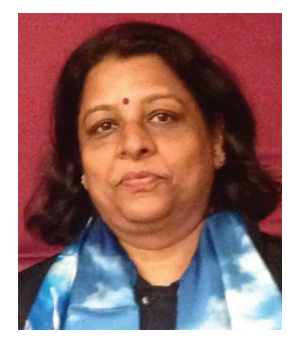

Rachana Garg (SM'10) received the B.E. and M.E. degree in 1986 and 1989 respectively from National Institute of Technology, Bhopal, India. She has obtained her Ph.D. in Electrical Engineering from Delhi University, India in 2009. Presently, she is working as Associate Professor in Delhi Technological University, Delhi, India. Her area of interest is modeling of transmission lines, power system operation and control, smart grid and renewable energy. 


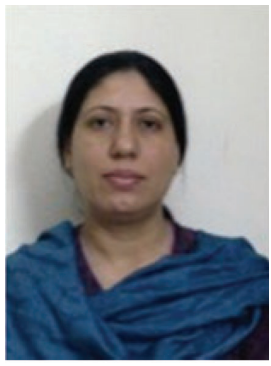

Alka Singh received the B.E. degree in engineering in Electrical Engineering from Delhi College of Engineering, Delhi, India, in 1996, the M.Tech. degree in Power Systems from the Indian Institute of Technology, New Delhi, India, in 2001, and the Ph.D. degree from Netaji Subash Institute of Technology (Delhi University), Delhi, India, in 2006. Currently, she is working as an Associate Professor in the Department of Electrical Engineering, Delhi Technological University, Delhi. Her research interests include power systems, power quality and application of power electronics to power systems. 
